made by a great number of small steps; and no sudden geographical revolution need be feared. To move with the times ought not to be very difficult, therefore, and to do so it is mainly necessary to look to the immediate future, or to take "short views of things," to use the words of that wise man Sydney Smith. If this policy be steadily pursued, there need be no cause for alarm for many years to come, at all events; for, as already suggested, plenty of geographical work yet remains to be done. We ought no doubt, in view of the changing conditions, to direct our efforts with more persistence than heretofore in the direction of encouraging travellers to make systematic and detailed examinations of comparatively small areas, and not merely to cover long distances with the result of doing little more than confirm the impressions of previous explorers. Their surveys should be as good as is possible in the circumstances, and the information they collect should be extensive, varied, systematic, and recorded with reference to the needs of the students of science and history, as well as of the man of commerce. In short, the traveller of the future ought to be a trained topographer, or to have thoroughly prepared himself in advance for some definite class of investigation.

As regards internal administration, the aim must be to make the society's house a place where accurate information can readily be obtained concerning all countries, including our own, the information thus supplied being all that could be described as geographical within the most elastic meaning of the word. The acquisition of suitable maps and books should, indeed, in future only be limited by financial necessity, whilst the collection of geographical photographs should be well maintained. No pains should be spared to make our systems of indexes as perfect as possible, a subject to which, as a fact, considerable attention has recently been paid; and with such aids the staff should be in a position to give every assistance to all students wishing to utilise the vast stores of information which the premises should contain. In short, we shall want more maps, more books, more photographs, and a more convenient house to hold both them and the steadily accumulating objects of interest which we own; and if the society continues to grow in usefulness on the lines suggested, we must look forward to the possibility of a material increase being needed in the number of the staff. Moreover, our means of keeping touch with foreign countries should be considered from time to time, to see if they are not capable of improvement. For example, as a single possible suggestion, might it not be worth considering whether British consuls, whilst actually serving abroad, should not be allowed to join our ranks with some special advantages as regards fees? Then, again, partly with the same object of facilitating the supply of information to our fellows, partly with the view of making our collections more generally useful, and partly in order to disarm the criticism made against us of wishing to poach on the preserves of other sciences, it might perhaps be well to allow the fellows of certain other learned societies to use our libraries with the same freedom with which they can now consult the maps in our map room.

As to the work of exploration and investigation for which we are not directly responsible, this should, as heretofore, continue to receive our warmest encouragement and our help when possible.

One other function which this society may always usefully perform, and one which has thus far been too much neglected. Science is cosmopolitan, and certainly the records of this society's proceedings during recent years, where the names of Sven Hedin, Peary, Charcôt, and many other distinguished foreign explorers so prominently appear, prove that this aspect of our duties is not now being overlooked. It is not, however, as it seems to me, in the least inconsistent with a belief in our world-wide obligations to hold that the work done by our fellowcountrymen has an especial claim on our attention, and that one of the aims of a national geographical society should be to keep alive the knowledge of the great deeds of British explorers in the past. Is it not probable that the history of Australia and New Zealand would have taken a very different turn if the work actually done by Captain Cook had been forestalled by some explorer owing nothing to these isles? And yet to that great man no NO. 2 I69, VOL. 86$]$ fitting monument has yet been erected. As to Africa, its map should have the names of our fellow-countrymen written all over it if intended to indicate the historical development of that continent-a development due in large measure to British exploration, the history of which we should never allow to die. In the case of thousands of adventurers who set forth to America and elsewhere from these islands in times gone by, and to whose exertions is fargely due the fact that English is now the most widely known language on the face of the earth, and that these islands hold in relation to their size an absolutely unique place in the history of the world, it is true that of these men we do not even know their names, though the effect of their exertions yet surrounds us on every side. It is to be hoped, therefore, that there will always exist in this land a body of men banded together with the object, amongst others, of making more widely known what was done by British explorers in the past, and of honouring the heroic spirit of these unnamed thousands which drove them forth to face untold dangers, and thus to help to build that Empire of which we are so proud.

\section{ORGANISATION AND PROGRESS IN ECONOMIC BIOLOGY.}

DURING the past decade economic biology has slowly but surely taken a definite place in our system of sciences in this country, and although at present but a sturdy infant, it would seem that it is destined to play no mean part in stimulating research and experimentation in the near future.

We have, fortunately, outgrown the prejudice that has for many years clung to practical science, and on all sides we can see investigations taking place of deep and farreaching scientific interest, but at the same time fraught with great import to man and his multifarious activities.

Once men begin to think and work along certain definite lines, it is not unnatural that they should seek to associate together, in order to discuss their methods of work, and the latest results obtained by their investigations. Without such association much unnecessary duplication of worl occurs, and the lack of organisation retards otherwise legitimate progress.

The foundation of the Association of Economic Biologists in November, 1904, was the outward expression of a feeling such as this that had long been simmering in the minds of economic biologists in the British Isles, and on the occasion of the tenth general meeting, which has recently been held at the University of Birmingham, where the first meeting took place, it seems not unnatural that we should pause and reffect upon the organisation and progress of this special branch of biological science.

During the life of the above association, meetings have been held at the universities of Birmingham, Liverpool, Cambridge, Edinburgh, Oxford, and Manchester, and one each at the Imperial Institute and University College, London. In looking at the list of papers read at these meetings, one cannot fail to be struck at the large amount of original work that has been carried out by the members, much of which has been published and adequately illustrated. The problems discussed relate to almost every subject wherein the economic biologist can aid or assist the physician, veterinarian, agriculturist, horticulturist, stock breeder, fruit grower, forester, fisherman, manufacturer, \&c. Since 1904 the members of this association have contributed in no small degree to the general advance that has been made in this particular science.

With progress and increased interest the workers also increase, and it is significant that at the last two meetings questions relating to organisation have figured prominently in the programmes. Few will forget Prof. Hickson's admirable address delivered last year at Manchester, on the place of economic zoology in a modern university, or the discussion that followed, both clearly indicating how fully it was realised that a sound scientific training was the best preparation for future specialisation.

In a more restricted sense, Mr. H. Maxwell Lefroy dealt with the training of economic entomologists at the last meeting. Mr. Lefroy has had a long and unique experience of the kind of men that are required in our colonies, but so far he has failed in his efforts to obtain such from 
this country. From his address we gather that he would dissociate entirely the training in entomology from the general zoological training, doing it as a post-graduate course. The trend of the course, he pointed out, must not be that of the comparative anatomist, the evolutionist, the systematist, or the histologist. The difficulty in making economic zoologists in England, he thought, would be the preponderance of the academic view and the total absence of the economic view based on experience. English universities have a very long way to go before they can turn out entomologists of the practical stamp that America does.

Referring to the lack of knowledge of entomology of the medical men who apply themselves to entomological problems, he described it as very painful, but in England there are so few places where medical men can obtain their training, and even then it seems to lack much. The kind of training in our universities is too academic for men who are required to solve problems requiring practical solutions.

We are on the threshold of greater things, and whatever problem comes one must put one's hand on. Only so is the practical entomologist going to convince an unlearned public and sceptical governments that there is anything at all in it, and we are, in England certainly, beginners who must look to the future. England should be the source at least of the entomologists of her Empire, but she is not, and unless radical changes take place in the atmosphere of her teachers, she will not be. The training will have to be that of practical field entomologists if the demand has to be met from England, and the last thing it wants is the academic zoological training of the average English university.

A perhaps more important subject to economic biologists generally was Mr. H. Maxwell Lefroy's address on the standardisation of economic nomenclature. The almost hopeless muddle that at present reigns in the nomenclature in the literature bearing on economic biology is little short of appalling.

Mr. Lefroy proposes to meet this difficulty by having a standard catalogue of the important species with the name most in use in biological literature definitely decided on, so that the further changes in nomenclature need not affect the economic biologist. The guiding principles would be that it should be independent or unaffected by the rules of priority. It should be based on the name used in important biological literature. Genera in which there is a close uniformity of habit and life-history, or which form a distinct class of pest, shall, for this purpose, be retained whole and not subdivided, e.g. Lecanium, Dactylopius, Agrotis, Gryllotalpa. To make existing and future biological literature accessible by adopting and making permanent the name under which it was written, and not to perpetuate inviolate the author of a name or description in the systematic literature. Writing recently on this subject, Mr. Lefroy stated, "In this matter, teachers and practical entomologists alone are concerned; to the systematic entomologist, the mazes of synonym and priority are (apparently) the breath of life, and the pastime might be a quite harmless one; . . . but to practical men who wish to check the growing spread of insects from country to country, who wish to cooperate to deal with big problems, who see in agricultural education the chief solution of these big problems, the question is one of vital importance. I think all economic entomologists will agree that we are immensely adding to the difficulties of our work, if it is to be anything more than parochial, either by modifying our nomenclature in accordance with the priority discoveries of systematists or by arbitrarily using the nomenclature we think most suitable. It is impossible for an isolated worker in a far country to do more than offer suggestions; I feel assured it will be for the permanent ultimate good of our science if we can overcome this growing monster, and I think the Association of Economic Biologists might fitly take up the subject."

As the outcome of Mr. Lefroy's suggestion it rvas decided to form a committee to consider and report upon the matter. The committee appointed were Richard $\mathrm{S}$. Bagnall, Prof. -Geo. H. Carpenter, H. Maxwell Lefroy, Dr. R. Stewart MacDougall, Robert Newstead, and Walter E. Collinge (hon. sec.).

NO. 2 I 69 , VOL. $86^{7}$
Such a scheme will greatly facilitate investigation and the reference to work done, and this desire to place matters upon a sound basis is perhaps one of the best auguries for the future prosperity of the association.

A further very interesting discussion was initiated by Dr. J. H. Priestley on the systematic recording of diseases of economic plants. The Biological Committee of the Agricultural Education Association have for some time past given consideration to the question of establishing at a convenient centre a record, as complete as possible, of the various fungus, insect, and other diseases of economic importance, reported in the British Isles from time to time. The main object of such a record would be to aid the scientific investigator who wished to get into touch as quickly as possible with the scattered literature and notes dealing with the distribution of, and other questions relating to, some disease or pest of which he was making a particular study. It had been decided to approach other bodies likely to be interested with a view to cooperation. It was decided to give the scheme approval and support.

All these activities indicate the growing importance of the subject, the possibilities of which we have yet but dimly realised; the multifarious lines of research are vast and the field is an ever widening one, and the need for work and workers pressing. That the workers of this country will bear their share in elucidating some of the hidden mysteries, and directing their application on the problems of our everyday life, is greatly to be hoped.

W. E. C

\section{ECOLOGICAL STUDIES.}

A NOTE by Dr. C. C. Hosseus on the flora of Wang Djao, a station on the Meping River in middle Siam, appears in Engler's Botanische Jahrbücher (vol. xlv., part iii.). Trees of Dipterocarpus laevis and other species clothed with epiphytes, especially orchids, are prominent along the river banks. On the savannah lands in the vicinity Cassia siamea is the dominant tree, while Andropogon brevifolius, species of Scitamineæ, and Hibiscus Abelmoschus are conspicuous amongst the ground vegetation.

In the Bulletin of the Illinois State Laboratory of Natural History (vol. ix., art. 3), Dr. H. A. Gleason presents an instructive ecological study of the vegetation of the inland sand deposits of Illinois. $\mathrm{He}$ distinguishes prairie, blowout, swamp, and forest formations. The prairie formation consists largely of bunch grass associations, in which Koeleria argentea, Leptoloma cognatum, Panicum pseudopubescens, and Andropogon scoparius are dominant species, either alone or in combination. On the patches between the grass clumps there grow various perennials of the type of Aster linariifolius, or Callirhoe triangulata, some annuals, and Selaginella rupestris, which spreads in circular rings. The formation and different aspects of the sand dune are described. The most efficient dune-formers are Panicum virgatum, which possesses long tough roots and tufted stems densely covered with persistent leaves, and a local variety of Rhus canadensis, which continually grows above the sand that collects around its dense tangle of stems.

A phytogeographical sketch of the Andes in the southeast of Bolivia, communicated by Mr. K. Fiebrig to Engler's Botanische Jahrbücher (vol. xlv., part i.), provides a good biological account of the remarkable modifications developed on the wind-swept high plateaux, the Punas, at an altitude of 12,000 feet. Cushion plants of a much branched, closely compacted character are displayed by Azorella madreporica and Pycnophyllum Pilgerianum, while a less extreme type is developed by many of the Compositæ, an Ephedra, and the globular cacti. Acaulescent long-rooted plants are exemplified by species of Astragalus, a new species of Alyssum, and Dalea callianthes. The numerous dwarf shrubs include many species of Compositæ, a Fabiana (Solanaceæ), and the thorny rosaceous plant, Tetraglochin strictum. Several bulbous plants occur, notably an Alstrœmeria and a grass-like Sisyrinchium, and an evil grass, Festuca orthophylla, covers extensive patches with porcupine-like leaves. Other formations described are the Alpine, the valleys, and the lowland forests. 